\title{
Perbaikan Proses Delivery Dokumen Maintenance C-Check Pesawat dengan Metode CCFE, FMEA, dan PICA (Studi Kasus di PT. GMF Aeroasia Tbk.)
}

\section{Improvement Of Aircraft C-Check Maintenance Document Delivery Process with CFME, FMEA, and PICA Methods (Case Study at PT. GMF Aeroasia Tbk.)}

\author{
Tina Hernawati Suryatman ${ }^{1}$, Muhammat Adi Putra ${ }^{2}$ \\ 1,2. Program Studi Teknik Industri, Fakultas Teknik, Universitas Muhammadiyah Tangerang \\ 1.tinahernawati76@gmail.com, ${ }^{2}$ putra581007@gmail.com
}

\begin{abstract}
PT. GMF Aeroasia, Tbk is a company engaged in aircraft maintenance services. The aircraft maintenance lead time is regulated according to the agreement set forth in the agreement in the form of a work order, when the maintenance process takes place there is almost always a delay when working on the aircraft, both in terms of physical work or delivery of documents. These problems are several forms of waste, where waste is any activity that does not provide added value. Therefore, the purpose of this study is to identify the type of waste and determine the factors that cause waste in the delivery process of aircraft c-check maintenance documents. The method used in this study used a fishbone chart, cause failure mode effect, failure mode and effects analysis and problem identification and corrective action. Fishbone chart and cause failure mode effect are used to find waste that causes delay in document delivery, then analyzed using failure mode and effects analysis, three causes of the highest delay were found, namely stamps on incomplete documents (RPN 16), waiting for customer approval (RPN 16) and material certificates not available (RPN 12). Corrective Action was prepared as a recommendation to improve the delivery process for aircraft c-check maintenance documents. By knowing the types of waste and the factors causing waste in the delivery process of aircraft c-check maintenance documents at PT. GMF Aeroasia Tbk is expected to reduce waste and fulfill customer satisfaction.
\end{abstract}

Keywords: Lead Time, Waste, Delay Delivery of Documents, Cause Failure Mode Effect Method, Corrective Action

\begin{abstract}
ABSTRAK
PT. GMF Aeroasia, Tbk merupakan perusahaan yang bergerak di bidang jasa perawatan pesawat udara. Lead time perawatan pesawat diatur sesuai dengan kesepakatan yang dituangkan dalam agreement berupa work order, saat proses perawatan berlangsung umumnya hampir selalu terjadi delay saat pengerjaan pesawat, baik dari segi pekerjaan fisik ataupun delivery dokumen. Permasalahan tersebut merupakan beberapa bentuk dari waste, dimana waste merupakan segala aktivitas yang tidak memberikan nilai tambah. Oleh karena itu tujuan penelitian ini mengidentifikasi jenis waste dan mengetahui faktor penyebab terjadinya waste dalam proses delivery dokumen maintenance c-check pesawat. Metode yang digunakan dalam penelitian menggunakan fishbone chart, cause failure mode effect, failure mode and effects analysis dan problem identification and corrective action. Fishbone chart dan cause failure mode effect digunakan untuk mencari waste penyebab delay delivery dokumen, lalu dianalisa menggunakan failure mode and effects analysis, didapatkan tiga penyebab delay tertinggi yaitu stamp pada dokumen tidak lengkap (RPN 16), menunggu approval costumer (RPN 16) dan sertifikat material tidak ada (RPN 12). Corrective Action di susun sebagai rekomendasi perbaikan proses delivery dokumen maintenance c-check pesawat. Dengan mengetahui jenis waste dan faktor penyebab waste pada proses delivery dokumen maintenance c-check pesawat di PT. GMF Aeroasia Tbk diharapkan dapat mengurangi waste dan kepuasan pelanggan terpenuhi.

Kata kunci: Lead Time, Waste, Delay Delivery Dokumen, Metode Cause Failure Mode Effect, Corrective Action
\end{abstract}




\section{PENDAhULUAN}

Industri penerbangan yang bergerak dibidang maintenance, repair dan overhaul semakin hari semakin berkembang. Hal ini disebabkan letak geografis Indonesia yang menyebabkan jumlah penerbangan sangat banyak di Indonesia. Dengan meningkatnya kebutuhan akan transportasi udara, maka industri di Indonesia yang berkaitan dengan dunia dirgantara mengalami perkembangan yang pesat

Maraknya pemakaian pesawat terbang oleh masyarakat maka secara tidak langsung, sebagian besar maskapai penerbangan harus memperluas armadanya. Perluasan tersebut dengan cara menambah jumlah pesawat terbang. Penambahan pesawat terbang oleh maskapai penerbangan tersebut biasannya dilakukan dengan cara menyewa pesawat dari perusahaan penyewa pesawat. Walaupun menyewa pesawat lebih menguntungkan, namun bisnis maskapai penerbangan memiliki banyak kelemahan, salah satunya adalah mahalnya biaya maintenance pesawat.

Maintenance pesawat merupakan salah satu komponen terbesar dari biaya belanja maskapai penerbangan dengan rata-rata sebesar $13 \%$, biaya terbesar lainnya berasal dari biaya bahan bakar dan biaya tenaga kerja. Dan tentunya masalah tersebut berkorelasi positif terhadap kebutuhan perawatan pesawat di dalam negeri. Karena itulah banyak peluang untuk mencari keuntungan di bidang penerbangan ini. Dan salah satunya adalah PT. GMF Aeroasia Tbk

PT. GMF Aeroasia Tbk merupakan perusahaan yang bergerak di bidang penyedia jasa, perbaikan, perawatan, dan overhaul (MRO) pesawat terbang. Penelitian yang dilakukan bertujuan untuk mengetahui pengaplikasian ilmu yang telah didapat dari bangku perkuliahan dalam dunia industri. Hal-hal yang dipelajari di PT. GMF Aeroasia Tbk. meliputi inspeksi pada pesawat, kerusakan pada pesawat serta cara perbaikan pada komponen pesawat yang rusak.

PT. GMF Aeroasia Tbk tidak hanya melayani maintenance pada pesawat dalam negri, namun juga melayani maskapai-maskapai yang berasal dari luar negri. Untuk maskapai dalam negri yang pernah melakukan maintenance di PT. GMF

Apabila masalah dan kendala tersebut tidak segera diselesaikan tentunya akan memunculkan masalah-masalah lain yang lebih kompleks yang akan merugikan perusahaan.

Tujuan dari penelitian ini adalah:

1. Mengidentifikasi faktor penyebab pemborosan (waste) saja pada proses delivery dokumen maintenance c-check pesawat di PT. GMF Aeroasia Tbk.

2. Menyusun corrective action untuk meminimasi pemborosan yang terjadi dalam proses delivery dokumen maintenance $c$-check pesawat di PT. GMF Aeroasia Tbk.

\section{METODELOGI PENELITIAN}

\section{Objek Penelitian}

Dalam penelitian ini yang menjadi objek adalah proses pelayanan jasa perawatan $C$-Check pesawat di PT GMF AeroAsia Tbk. PT GMF AeroAsia Tbk adalah perusahaan Maintenance Repair Organization (MRO) yang berbasis di Tangerang, Banten, Indonesia. PT. GMF Aeroasia. Tbk adalah perusahaan yang memberikan layanan perawatan pesawat dari berbagai jenis dan merupakan salah satu fasilitas perawatan pesawat terbesar di Asia.

\section{Teknik Pengumpulan Data}

\section{Data Primer}

1. Kegiatan observasi dilakukan dengan mengumpulkan data yang dibutuhkan dalam penelitian dimana data tersebut diambil langsung dilokasi penelitian, data yang diambil pada proses perawatan $C$ check pesawat berbadan kecil yang ada di PT. GMF Aeroasia.Tbk dalam memberikan pelayanan perawatan pesawat dari awal proses sampai semua proses pengerjaan jobcard perawatan $\mathrm{C}$ check pesawat selesai dan dokumen kerja selesai dan sudah dilakukan stamping dan kemudian pesawat realese untuk return to service. 
2. wawancara dilakukan dengan mengumpulkan data penunjang diperoleh dari wawancara dengan Aircraft Project Leader, Senior Aircraft Maintenance Engineer, Senior Aircraft Structure Engineer, Senior Aircraft Cabin Engineer, Senior Aircraft Purchaser, Senior Aircraft Quality Inspector, Staff PPC \& Texhnical Representatif (Customer)

\section{Data sekunder}

Data sekundernya yaitu data perusahaan dan data project perawatan $C$ check pesawat.

\section{Teknik Analisis Data}

Data yang terkumpul akan diolah menggunakan diagram SIPOC, diagram pareto dan fishbone diagram. Waste dianalisis menggunakan Cause-Failure Mode-Effect (CFME) dan Failure Mode and Effects Analysis (FMEA) untuk mengidentifikasi dan menilai resikoresiko yang berhubungan dengn potensi terjadinya suatu kegagalan, selanjutnya disusun Problem Identification and Corrective Action (PICA) sebagai rekomendasi perbaikan proses untuk meminimasi waste.

\section{HASIL DAN PEMBAHASAN}

Data diperoleh dari unit TJP-4 (Maintenance Record). Data-data tersebut berisi Job Card dan MD, yang merupakan catatan historical tentang perawatan pesawat. Dari data yang diperoleh dari sistem kontrol unit TJP-4 (Maintenance Record), terdapat 72 delivery dokumen yang telah dikirim ke pelanggan, 38 diantaranya mengalami keterlambatan pengiriman, dikarenakan pengiriman dokumen melewati batas waktu yang telah ditentukan. Hal ini menjadi permasalahan yang perlu mendapat penanganan lebih mendetail. Oleh karena itu diperlukan analisis hasil pencapaian Turn Around Time antara target yang ingin dicapai dengan realisasi.

Tabel 1. SIPOC Diagram Proses Delivery Dokumen

\begin{tabular}{|c|c|c|c|c|}
\hline SUPPLIER & INPUT & PROCESS & OUTPUT & COSTUMER \\
\hline \multirow{6}{*}{ Produksi } & \multirow{6}{*}{ Dokumen } & $\begin{array}{l}\text { Mengumpulkan } \\
\text { dokumen }\end{array}$ & \multirow{3}{*}{$\begin{array}{c}\text { File Softcopy } \\
\text { Maintenance } \\
\text { Record }\end{array}$} & \multirow{6}{*}{ Airline } \\
\hline & & $\begin{array}{c}\text { Review } \\
\text { dokumen }\end{array}$ & & \\
\hline & & $\begin{array}{l}\text { Scanning } \\
\text { dokumen }\end{array}$ & & \\
\hline & & $\begin{array}{c}\text { Recheck hasil } \\
\text { scan }\end{array}$ & \multirow{3}{*}{$\begin{array}{c}\text { Paket } \\
\text { Jobcard dan } \\
M D R\end{array}$} & \\
\hline & & $\begin{array}{c}\text { Pengemasan } \\
\text { dokumen }\end{array}$ & & \\
\hline & & $\begin{array}{c}\text { Mengirim ke } \\
\text { costumer }\end{array}$ & & \\
\hline
\end{tabular}

Sumber: Hasil Olah Data

Line produksi menjadi dasar dimulainya proses delivery dokumen sebagai supplier. Dokumen pekerjaan (Jobcard dan MDR) yang telah selesai dikerjakan di line produksi menjadi bagian dari input. Mengumpulkan dokumen, review dokumen, scanning dokumen, recheck hasil scan, pengemasan dokumen dan mengirim ke costumer sebagai process. File softcopy maintenance record serta paket jobcard dan MDR adalah output dari proses. File softcopy maintenance record serta paket jobcard dan MDR ini lah yang nantinya akan ditagihkan ke costumer atau airline untuk mendapatkan revenue.

\section{Diagram Pareto}

Delivery dokumen pesawat diolah dengan menggunakan Diagram Pareto untuk mengetahui prosentase urutan delay terbesar sampai terkecil selama periode September 2019 - Februari 2020. Data dihitung dengan rumus sebagai berikut:

$\%$ Jumlah Delayed $=$ Bulan Delayed $\div$ Jumlah Delayed $\times 100 \%$

Contoh perhitungan presentase delay:

$\%$ Jumlah Delayed $=10 \div 38 \times 100 \%=26.31 \%$ 
Tabel 2. Persentase dari Delay Keseluruhan

\begin{tabular}{ccccc}
\hline No & Bulan & Delayed & Persentase (\%) & Kumulatif \\
\hline $\mathbf{1}$ & November & 10 & 26.31 & 26.31 \\
\hline $\mathbf{2}$ & Februari & 8 & 21.05 & 47.36 \\
\hline $\mathbf{3}$ & Desember & 7 & 18.42 & 65.78 \\
\hline $\mathbf{4}$ & Oktober & 6 & 15.78 & 81.56 \\
\hline $\mathbf{5}$ & September & 4 & 10.52 & 92.08 \\
\hline $\mathbf{6}$ & Januari & 3 & 7.89 & 100 \\
\hline & Jumlah & $\mathbf{3 8}$ & & \\
\hline
\end{tabular}

Sumber: Hasil Olah Data

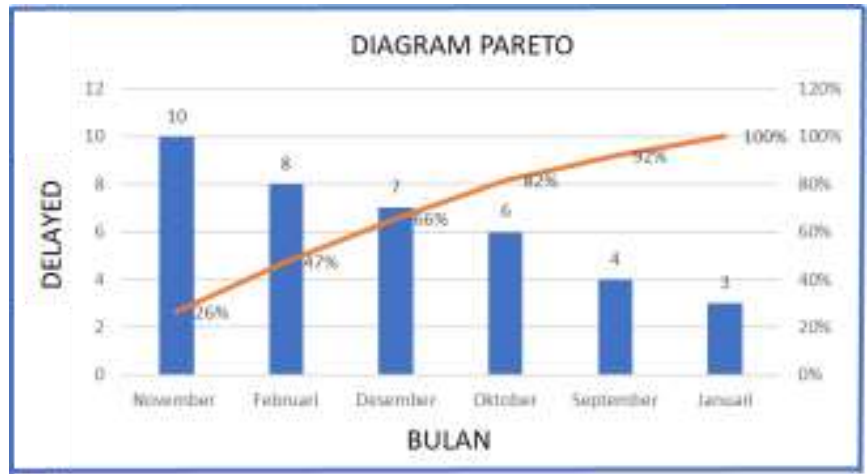

Gambar 1. Diagram Pareto Delay Keseluruhan Sumber: Hasil Olah Data

\section{Diagram Sebab Akibat (Fishbone)}

Diagram sebab akibat digunakan untuk mengetahui faktor-faktor yang mempengaruhi atau menyebabkan terjadinya delay delivery dokumen.

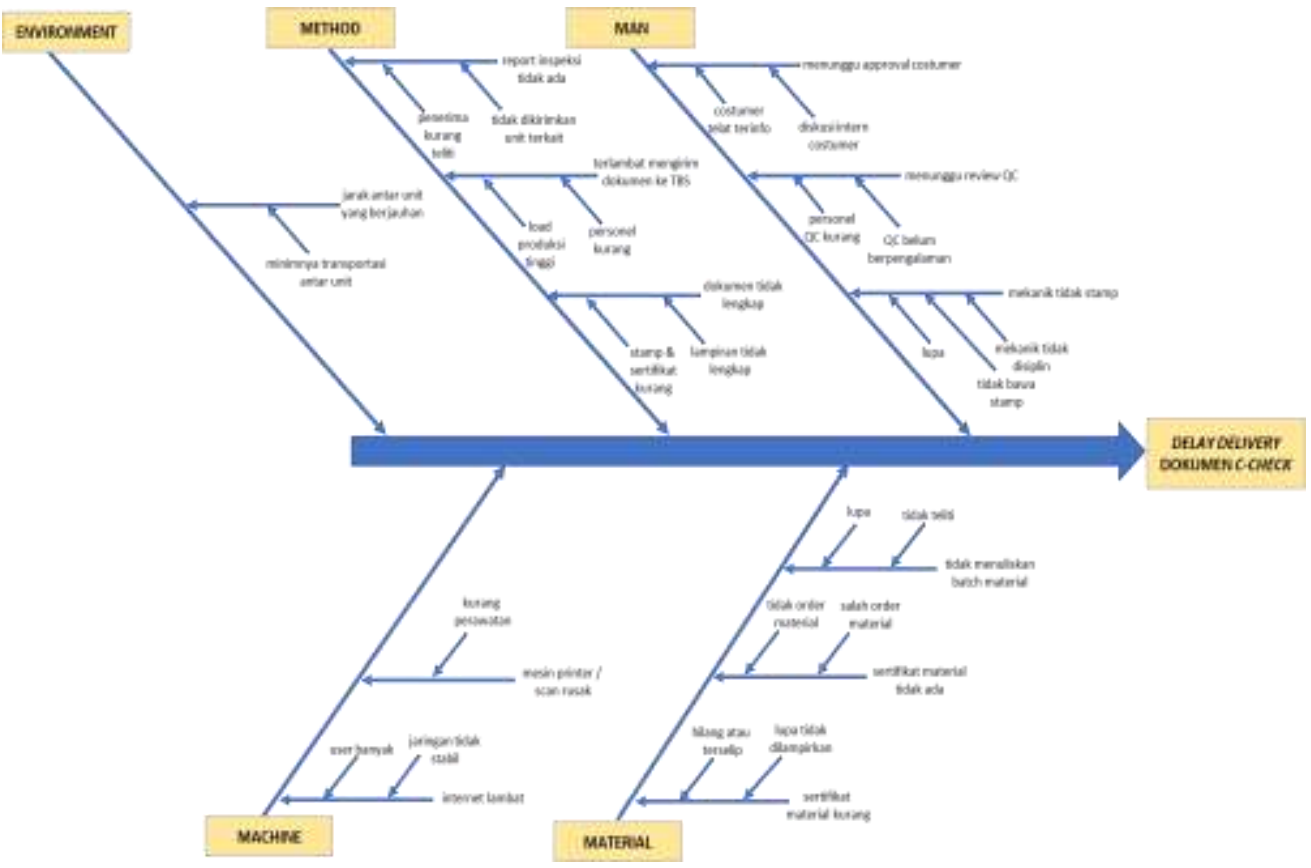

Gambar 2. Diagram Fishbone Delay Delivery Dokumen C-Check Sumber: Hasil Olah Data

Berdasarkan diagram pareto dan fishbone diagram telah diketahui 5 faktor penyebab terjadinya delay delivery dokumen maintenance c-check pesawat. 


\section{Cause-Failure Mode-Effect (CFME)}

CFME merupakan pengembangan dari diagram sebab-akibat dan digunakan untuk mencari akar permasalahan dari penyebab yang sudah diketahui. Hasil CFME untuk Delay Delivery Dokumen $C$-Check

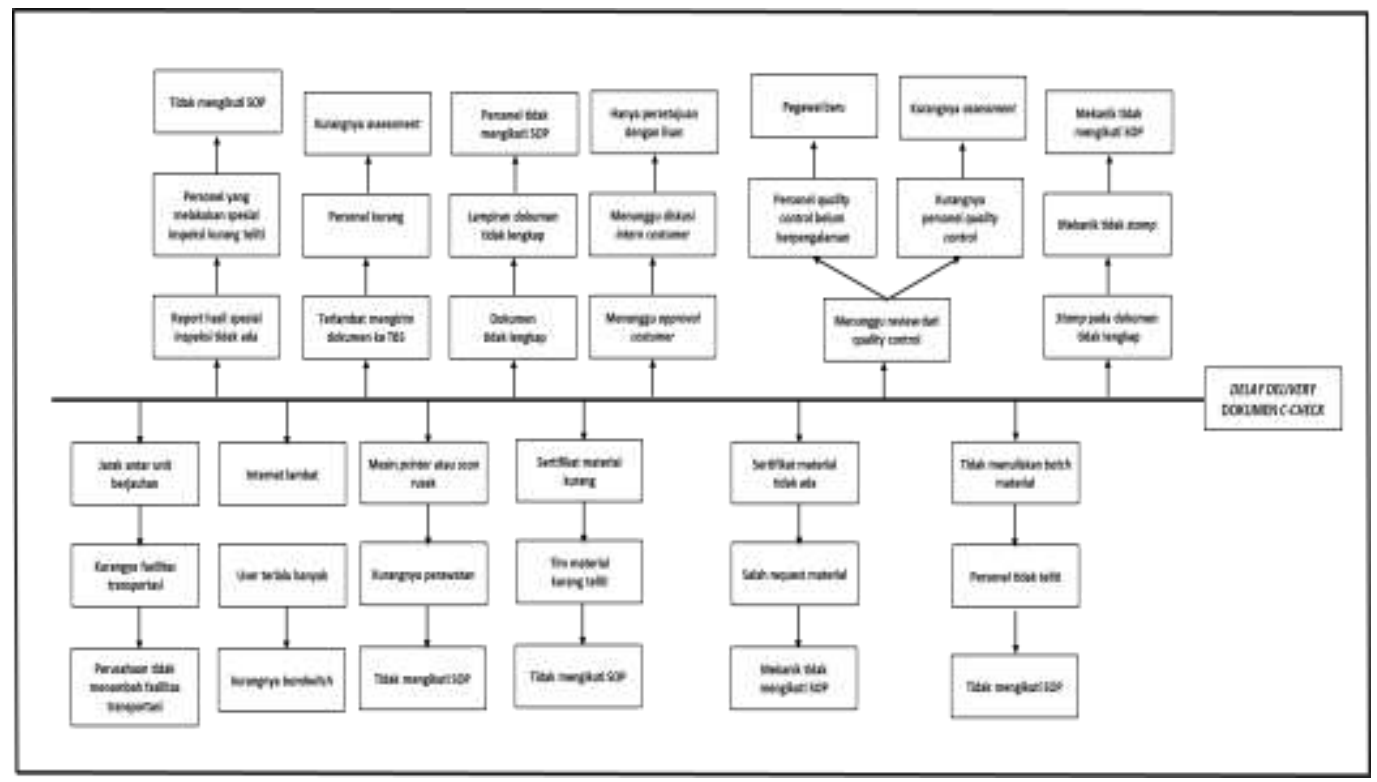

Gambar 3. Cause-Failure Mode-Effect (CFME)

Sumber: Hasil Olah Data

Dari diagram CFME, yang menjadi karakteristik dan akan dicari penyebab (cause), modus kegagalan (failure mode) dan efeknya adalah delay delivery dokumen maintenance c-check. Bagian kotak yang paling atas adalah akar penyebab masalah atau sumber variasi yang menyebabkan terjadinya delay delivery dokumen maintenance c-check. Sementara itu, kotak sebelum akar permasalahan adalah yang menjadi modus kegagalan dan kotak yang sesudah modus kegagalan adalah efeknya. Jadi yang diambil kedalam tabel FMEA adalah 3 kotak terakhir dari masing-masing cabang yang ada di diagram CFME. Teknik CFME mengidentifikasi akar penyebab masalah sehingga penanganan masalahnya langsung dilakukan pada akar masalah. Diagram CFME penting agar tidak terjadi kesalahan, misalnya yang seharusnya menjadi modus kegagalan dinyatakan sebagai efek atau yang seharusnya menjadi efek dinyatakan sebagai modus kegagalan.

Dari hasil CFME yang berupa urutan akar penyebab masalah, modus kegagalan dan efek dirangkum ke dalam tabel FMEA. Adapun skala yang digunakan untuk menilai masing-masing penyebab adalah 1-5. Hal ini untuk lebih memudahkan perhitungan. 
Tabel 3. Hasil Pengolahan FMEA untuk Delay Delivery Dokumen Maintenance C-Check

\begin{tabular}{|c|c|c|c|c|c|c|c|c|}
\hline \multirow{2}{*}{$\begin{array}{c}\text { Karakteristik } \\
\text { Diharapkan }\end{array}$} & \multirow{2}{*}{$\begin{array}{c}\text { Modus } \\
\text { Kegagalan } \\
\text { Potensial } \\
\end{array}$} & \multirow{2}{*}{$\begin{array}{c}\text { Efek Kegagalan } \\
\text { Potensial }\end{array}$} & \multirow{2}{*}{$\begin{array}{l}\text { Penyebab } \\
\text { Potensial }\end{array}$} & \multirow{2}{*}{$\begin{array}{l}\text { Current } \\
\text { control }\end{array}$} & \multicolumn{3}{|c|}{ Nilai } & \multirow{2}{*}{$\begin{array}{c}\text { RPN } \\
\text { S } \times \text { O } \times \text { D } \\
\end{array}$} \\
\hline & & & & & $\mathbf{S}$ & $\mathbf{O}$ & D & \\
\hline \multirow{10}{*}{$\begin{array}{l}\text { Tidak terjadi } \\
\text { delay delivery } \\
\text { dokumen }\end{array}$} & $\begin{array}{l}\text { Mekanik tidak } \\
\text { stamp }\end{array}$ & $\begin{array}{l}\text { Stamp pada dokumen } \\
\text { tidak lengkap }\end{array}$ & $\begin{array}{l}\text { Mekanik tidak } \\
\text { mengikuti SOP }\end{array}$ & Tidak ada & 2 & 4 & 2 & 16 \\
\hline & $\begin{array}{c}\text { Kurangnya } \\
\text { personel quality } \\
\text { control }\end{array}$ & \multirow{2}{*}{$\begin{array}{l}\text { Mengunggu review } \\
\text { dari quality control }\end{array}$} & $\begin{array}{l}\text { Kurangnya } \\
\text { assessment }\end{array}$ & Tidak ada & 2 & 2 & 2 & 8 \\
\hline & $\begin{array}{c}\text { Personel quality } \\
\text { control belum } \\
\text { berpengalaman }\end{array}$ & & Pegawai baru & $\begin{array}{l}\text { Pelatihan/ } \\
\text { training }\end{array}$ & 2 & 2 & 2 & 8 \\
\hline & $\begin{array}{l}\text { Menunggu diskusi } \\
\text { intern costumer }\end{array}$ & $\begin{array}{c}\text { Menunggu approval } \\
\text { costumer }\end{array}$ & $\begin{array}{c}\text { Hanya } \\
\text { persetujuan via } \\
\text { lisan }\end{array}$ & $\begin{array}{l}\text { Project } \\
\text { Owner }\end{array}$ & 4 & 1 & 4 & 16 \\
\hline & $\begin{array}{c}\text { Lampiran } \\
\text { dokumen tidak } \\
\text { lengkap }\end{array}$ & $\begin{array}{l}\text { Dokumen tidak } \\
\text { lengkap }\end{array}$ & $\begin{array}{l}\text { Personel tidak } \\
\text { mengikuti SOP }\end{array}$ & Tidak ada & 1 & 3 & 2 & 6 \\
\hline & Personel kurang & $\begin{array}{c}\text { Terlambat mengirim } \\
\text { dokumen ke TBS }\end{array}$ & $\begin{array}{l}\text { Kurangnya } \\
\text { assessment }\end{array}$ & $\begin{array}{c}\text { Manager } \\
\text { terkait }\end{array}$ & 2 & 1 & 2 & 4 \\
\hline & \begin{tabular}{|c|} 
Personel yang \\
melakukan special \\
inspeksi kurang \\
teliti \\
\end{tabular} & $\begin{array}{l}\text { Report hasil special } \\
\text { inspeksi tidak ada }\end{array}$ & $\begin{array}{c}\text { Tidak mengikuti } \\
\text { SOP }\end{array}$ & Tidak ada & 2 & 1 & 2 & 4 \\
\hline & $\begin{array}{l}\text { Personel tidak } \\
\text { teliti }\end{array}$ & $\begin{array}{l}\text { Tidak menuliskan } \\
\text { batch material }\end{array}$ & $\begin{array}{c}\text { Tidak mengikuti } \\
\text { SOP }\end{array}$ & Tidak ada & 1 & 4 & 2 & 8 \\
\hline & $\begin{array}{l}\text { Salah request } \\
\text { material }\end{array}$ & $\begin{array}{c}\text { Sertifikat material } \\
\text { tidak ada }\end{array}$ & $\begin{array}{l}\text { Mekanik tidak } \\
\text { mengikuti SOP }\end{array}$ & Tidak ada & 3 & 1 & 4 & 12 \\
\hline & $\begin{array}{l}\text { Tim material } \\
\text { kurang teliti }\end{array}$ & $\begin{array}{l}\text { Sertifikat material } \\
\text { kurang }\end{array}$ & $\begin{array}{c}\text { Tidak mengikuti } \\
\text { SOP }\end{array}$ & Tidak ada & 1 & 3 & 2 & 6 \\
\hline \multirow{3}{*}{$\begin{array}{l}\text { Tidak terjadi } \\
\text { delay delivery } \\
\text { dokumen }\end{array}$} & $\begin{array}{c}\text { Kurangnya } \\
\text { perawatan mesin } \\
\text { printer atau scan }\end{array}$ & $\begin{array}{l}\text { Mesin printer atau } \\
\text { scan rusak }\end{array}$ & $\begin{array}{c}\text { Tidak mengikuti } \\
\text { SOP }\end{array}$ & $\begin{array}{c}\text { Unit } \\
\text { Facility }\end{array}$ & 3 & 1 & 2 & 6 \\
\hline & $\begin{array}{c}\text { User internet } \\
\text { terlalu banyak }\end{array}$ & Internet lambat & $\begin{array}{l}\text { Kurangnya } \\
\text { bandwitch } \\
\text { internet }\end{array}$ & Tim IT & 2 & 2 & 2 & 8 \\
\hline & $\begin{array}{l}\text { Kurangnya } \\
\text { fasilitas } \\
\text { transportasi }\end{array}$ & $\begin{array}{l}\text { Jarak antar unit } \\
\text { berjauhan }\end{array}$ & $\begin{array}{c}\text { Perusahaan tidak } \\
\text { menambah } \\
\text { fasilitas } \\
\text { transportasi }\end{array}$ & $\begin{array}{c}\text { Unit } \\
\text { Facility }\end{array}$ & 1 & 3 & 2 & 6 \\
\hline
\end{tabular}

Dari berbagai modus kegagalan yang ada di tabel FMEA, diambil 3 modus paling tinggi untuk kemudian dianalisa lebih lanjut. Berikut ini adalah analisanya:

1. Stamp pada dokumen tidak lengkap

Waste ini memiliki severity yang tidak terlalu besar, namun tingkat occurancenya cukup tinggi. Stamp pada dokumen merupakan bukti bahwa pekerjaan sudah dilakukan. Membubuhkan stamp pada dokumen merupakan hal yang mudah, namun apabila personel yang melakukan pekerjaan maintenance tidak men-stamp dokumen, maka dokumen tersebut tidak akan bisa diselesaikan. Begitu juga apabila proses re-stamp akan dilakukan namun personel yang bersangkutan sedang tidak ditempat atau cuti maka harus menunggu personel tersebut sampai datang, karena sesuai quality prosedur stamp harus selalu dibawa oleh personel dan tidak boleh dititipkan ke personel lain. Stamp tersebut juga mewakili tanggung jawab atas apa yang telah personel kerjakan sesuai instruksi pada dokumen tersebut. Disini seharusnya setiap personel mengikuti SOP yang sesuai dengan 
quality prosedure, yakni setiap selesai melakukan satu langkah pekerjaan, dokumen pekerjaannya harus langsung distamp dan diberi tanggal. Apabila hal ini dilakukan oleh setiap personel maka waste ini bisa diminimalisir.

2. Menunggu approval costumer

Waste ini memiliki tingkat occurance yang sangat rendah namun memiliki tingkat severity cukup tinggi. Disini salah satu penyebab utamanya adalah persetujuan antara project owner dan costumer ketika meeting hanya berupa pernyataan lisan. Hal ini bisa terjadi karena dalam satu project maintenance pesawat hanya memiliki satu project owner dan satu project leader. Sedangkan pekerjaan project owner dan project leader adalah mensupervisi dan bertanggungjawab atas semua item yang dikerjakan selama proses maintenance pesawat berlangsung. Dan item yang dikerjakan selama proses maintenance pesawat berlangsung mencapai ribuan item. Sehingga ketika memiliki load pekerjaan yang sangat banyak, namun antara project owner dan project leader kurang baik ketika bekerja sama maka hal ini bisa terjadi.

3. Sertifikat material tidak ada

Waste ini memiliki severity yang tidak terlalu besar, namun tingkat occurancenya cukup tinggi. Waste ini disebabkan oleh personel yang sudah memiliki stok material, namun salah menulis part number material pada dokumen sehingga ketika sertifikat material akan dicari, tidak ditemukan dsistem. Cara menyelesaikan permasalahan ini adalah dengan nenanyakan langsung ke personel yang melakukan request material. Masalah terbesarnya adalah apabila personel tersebut tidak ditempat atau sedang cuti, dan rekannya yang lain tidak mengetahui perihal pekerjaan tersebut. Hal ini lah yang menyebabkan waktu yang terbuang cukup lama.

Disini seharusnya setiap personel mengikuti SOP yang sesuai dengan quality prosedur, yakni setiap melakukan request material, harus mengecek part number yang dimasukkan ke dokumen, supaya tidak terjadi kesalahan. Karena salah satu angka atau huruf saja maka material yang dimaksud bisa jadi tidak exist di sistem.

\section{Problem Identification and Corrective Action (PICA)}

Salah satu tools yang digunakan dalam tahap ini adalah PICA. Di dalam PICA terdapat keterangan mengenai perbaikan apa yang perlu dilakukan terhadap masing-masing penyebab masalah dan juga penjelasan mengenai bagaimana perbaikan tersebut dapat dilaksanakan. Disini diberikan masukan-masukan dan usulan perbaikan terhadap proses berdasatkan analisis identifikasi penyebab waste yang telah dibuat sebelumnya.

Penjabaran usulan perbaikan yang berbentuk tabel PICA tersebut dapat dilihat pada Tabel 4 berikut

Tabel 4. Problem Identification and Corrective Action (PICA)

\begin{tabular}{|c|c|c|c|c|c|c|c|}
\hline No & Masalah & Perbaikan & Mengapa & Bagaimana & Kapan & Dimana & PIC \\
\hline \multirow[t]{2}{*}{1} & \multirow[t]{2}{*}{$\begin{array}{l}\text { Stamp pada } \\
\text { dokumen tidak } \\
\text { lengkap karena } \\
\text { mekanik tidak } \\
\text { stamp setelah } \\
\text { melakukan } \\
\text { pekerjaan }\end{array}$} & \multirow[t]{2}{*}{$\begin{array}{c}\text { Memberikan } \\
\text { pengarahan prosedur } \\
\text { kerja yang sesuai } \\
\text { SOP oleh manager } \\
\text { setiap briefing } \\
\text { sebelum mulai } \\
\text { melakukan } \\
\text { pekerjaan }\end{array}$} & \multirow[t]{2}{*}{$\begin{array}{c}\text { Meningkatkan } \\
\text { awareness } \\
\text { mengenai } \\
\text { pentingnya } \\
\text { melakukan stamp } \\
\text { pada setiap } \\
\text { pekerjaan }\end{array}$} & $\begin{array}{c}\text { Manager melakukan } \\
\text { briefing kepada sub } \\
\text { koordinatnya } \\
\text { mengenai } \\
\text { pentingnya } \\
\text { melakukan stamp } \\
\text { pada dokumen setiap } \\
\text { selesai pekerjaan } \\
\text { (minimal per } 3 \text { hari) }\end{array}$ & & $\begin{array}{c}\text { Line } \\
\text { Produksi }\end{array}$ & Manager \\
\hline & & & & $\begin{array}{l}\text { Memberikan sanksi } \\
\text { administratif kepada } \\
\text { mekanik yang tidak } \\
\text { melakukan stamp }\end{array}$ & & $\begin{array}{c}\text { Line } \\
\text { Products }\end{array}$ & Manager \\
\hline 2 & \begin{tabular}{|} 
Mengunggu \\
review dari \\
quality control \\
\end{tabular} & $\begin{array}{l}\text { Menambah personel } \\
\text { quality control yang } \\
\text { berpengalaman }\end{array}$ & $\begin{array}{l}\text { Meningkatkan } \\
\text { kecepatan dalam } \\
\text { me-review }\end{array}$ & $\begin{array}{l}\text { Menambah personel } \\
\text { quality control yang } \\
\text { berpengalaman }\end{array}$ & & $\begin{array}{c}\text { Line } \\
\text { Produksi }\end{array}$ & QC \\
\hline
\end{tabular}


Tabel 4. Problem Identification and Corrective Action (PICA)

\begin{tabular}{|c|c|c|c|c|c|c|c|}
\hline No & Masalah & Perbaikan & Mengapa & Bagaimana & Kapan & Dimana & PIC \\
\hline & \multirow{3}{*}{\begin{tabular}{|c|} 
karena \\
kurangnya \\
personel \\
quality control \\
dan personel \\
quality control \\
belum \\
berpengalaman
\end{tabular}} & & \multirow{3}{*}{$\begin{array}{l}\text { dokumen dan } \\
\text { mengurangi } \\
\text { human error }\end{array}$} & $\begin{array}{l}\text { sesuai dengan } \\
\text { kebutuhan }\end{array}$ & & & \\
\hline & & & & $\begin{array}{l}\text { Training mengenai } \\
\text { pekerjaan yang } \\
\text { dilakukan oleh } \\
\text { expert untuk } \\
\text { personel quality } \\
\text { control yang baru } \\
\text { secara periodik (per } \\
3 \text { bulan) untuk } \\
\text { meningkatkan } \\
\text { keahlian dan } \\
\text { Ketelitian }\end{array}$ & & $\begin{array}{l}\text { Line } \\
\text { Produksi }\end{array}$ & QC \\
\hline & & & & $\begin{array}{l}\text { Membiasakan } \\
\text { budaya berbagi ilmu } \\
\text { di antara personel } \\
\text { quality control, } \\
\text { khususnya antara } \\
\text { senior dan junior }\end{array}$ & & $\begin{array}{c}\text { Line } \\
\text { Produksi }\end{array}$ & QC \\
\hline \multirow[t]{2}{*}{3} & \multirow{2}{*}{$\begin{array}{l}\text { Menunggu } \\
\text { approval } \\
\text { costumer } \\
\text { karena } \\
\text { Menunggu } \\
\text { diskusi intern } \\
\text { costumer }\end{array}$} & \multirow{2}{*}{$\begin{array}{l}\text { Agreement dengan } \\
\text { costumer hendaknya } \\
\text { segera di follow up } \\
\text { dan disertai dengan } \\
\text { statement letter atau } \\
\text { email resmi }\end{array}$} & \multirow{2}{*}{$\begin{array}{l}\text { Untuk mencegah } \\
\text { miscommunicatio } \\
n \text { dengan } \\
\text { costumer }\end{array}$} & $\begin{array}{l}\text { Segera mem-follow } \\
\text { up pernyataan } \\
\text { costumer apabila } \\
\text { sudah terjadi } \\
\text { kesepakatan }\end{array}$ & & $\begin{array}{l}\text { Line } \\
\text { Produksi }\end{array}$ & $\mathrm{PO}$ \\
\hline & & & & $\begin{array}{l}\text { Agreement } \\
\text { hendaknya disertai } \\
\text { email resmi atau } \\
\text { statement letter }\end{array}$ & & $\begin{array}{c}\text { Line } \\
\text { Produksi }\end{array}$ & $\mathrm{PO}$ \\
\hline 4 & $\begin{array}{c}\text { MDR atau } \\
\text { jobcard tidak } \\
\text { lengkap karena } \\
\text { lampirannya } \\
\text { tidak lengkap }\end{array}$ & $\begin{array}{l}\text { Planner atau } \\
\text { production } \\
\text { engineering } \\
\text { melakukan double } \\
\text { check ketika } \\
\text { dokumen pekerjan } \\
\text { diterbitkan }\end{array}$ & $\begin{array}{l}\text { Untuk mencegah } \\
\text { komplain } \\
\text { costumer ketika } \\
\text { dokumen di } \\
\text { review oleh } \\
\text { costumer }\end{array}$ & $\begin{array}{l}\text { Setiap selesai } \\
\text { menerbitkan jobcard } \\
\text { atau MDR planner } \\
\text { atau production } \\
\text { engineering } \\
\text { melakukan double } \\
\text { check kelengkapan } \\
\text { task dan } \\
\text { lampirannya }\end{array}$ & & $\begin{array}{c}\text { Line } \\
\text { Produksi }\end{array}$ & Produksi \\
\hline \multirow[b]{2}{*}{5} & \multirow[b]{2}{*}{$\begin{array}{l}\text { Terlambat } \\
\text { mengirim } \\
\text { dokumen ke } \\
\text { TBS karena } \\
\text { personel } \\
\text { kurang }\end{array}$} & \multirow[b]{2}{*}{$\begin{array}{l}\text { Menambah personel } \\
\text { PPC unit }\end{array}$} & \multirow[b]{2}{*}{$\begin{array}{l}\text { Meningkatkan } \\
\text { kecepatan dalam } \\
\text { pengiriman dari } \\
\text { PPC unit ke TBS }\end{array}$} & $\begin{array}{l}\text { Menambah personel } \\
\text { PPC unit sesuai } \\
\text { dengan kebutuhan }\end{array}$ & & $\begin{array}{c}\text { Line } \\
\text { Produksi }\end{array}$ & Manager \\
\hline & & & & \begin{tabular}{|l|} 
Memberi tahu \\
personel TBS agar \\
dapat membantu \\
mengambil dokumen \\
yang sudah komplit \\
ketika load produksi \\
sedang tinggi
\end{tabular} & & $\begin{array}{c}\text { Line } \\
\text { Produksi }\end{array}$ & Produksi \\
\hline 6 & $\begin{array}{l}\text { Report hasil } \\
\text { spesial } \\
\text { inspeksi tidak } \\
\text { ada karena } \\
\text { personel yang } \\
\text { melakukan } \\
\text { pekerjaannya } \\
\text { tidak }\end{array}$ & $\begin{array}{l}\text { Dilakukan } \\
\text { pengontrolan oleh } \\
\text { PPC unit untuk } \\
\text { menanyakan report } \\
\text { hasil inspeksi jika } \\
\text { ada pekerjaan } \\
\text { inspeksi khusus. }\end{array}$ & $\begin{array}{l}\text { Untuk mencegah } \\
\text { report hasil } \\
\text { inspeksi tidak } \\
\text { terlampir dalam } \\
\text { jobcad atau MDR } \\
\text { dan menambah } \\
\text { kecepatan } \\
\text { closing dokumen }\end{array}$ & $\begin{array}{l}\text { PPC unit hendaknya } \\
\text { lebih teliti dalam } \\
\text { menerima jobcard } \\
\text { atau MDR yang } \\
\text { berhubungan dengan } \\
\text { spesial inspeksi }\end{array}$ & & $\begin{array}{c}\text { Line } \\
\text { Produksi }\end{array}$ & Produksi \\
\hline
\end{tabular}

JIM, Vol. 6, No. 2, Agustus 2021, pp.131 - 144 
Tabel 4. Problem Identification and Corrective Action (PICA)

\begin{tabular}{|c|c|c|c|c|c|c|c|}
\hline No & Masalah & Perbaikan & Mengapa & Bagaimana & Kapan & Dimana & PIC \\
\hline & $\begin{array}{c}\text { melampirkan } \\
\text { report hasil } \\
\text { inspeksinya }\end{array}$ & & & & & & \\
\hline \multirow[t]{2}{*}{7} & \multirow[t]{2}{*}{\begin{tabular}{|} 
Tidak \\
menuliskan \\
batch material \\
karena \\
personel tidak \\
teliti
\end{tabular}} & \multirow[t]{2}{*}{$\begin{array}{l}\text { Dibuatkan check } \\
\text { sheet penerimaan } \\
\text { dokumen oleh tim } \\
\text { TBS }\end{array}$} & \multirow[t]{2}{*}{$\begin{array}{l}\text { Meningkatkan } \\
\text { kecepatan } \\
\text { closing dokumen }\end{array}$} & $\begin{array}{l}\text { TBS membuat } \text { check } \\
\text { sheet penerimaan } \\
\text { dokumen, dengan } \\
\text { menggunakan } \text { check } \\
\text { sheet dokumen yang } \\
\text { diterima oleh TBS } \\
\text { diharapkan sudah } \\
\text { sesuai dengan daftar } \\
\text { yang ada pada } \text { check } \\
\text { sheet tersebut. }\end{array}$ & & $\begin{array}{c}\text { Line } \\
\text { Produksi }\end{array}$ & Produksi \\
\hline & & & & $\begin{array}{l}\text { PPC unit melakukan } \\
\text { pengontrolan } \\
\text { dokumen sebelum } \\
\text { dokumen dikirim ke } \\
\text { TBS }\end{array}$ & & $\begin{array}{c}\text { Line } \\
\text { Produksi }\end{array}$ & Produksi \\
\hline 8 & $\begin{array}{c}\text { Sertifikat } \\
\text { material tidak } \\
\text { ada karena } \\
\text { salah request } \\
\text { material }\end{array}$ & $\begin{array}{l}\text { Mekanik yang me- } \\
\text { request material } \\
\text { hendaknya } \\
\text { mengecek apakah } \\
\text { part number sudah } \\
\text { sesuai reference dan } \\
\text { memastikan } \\
\text { penulisan part } \\
\text { number sudah benar }\end{array}$ & $\begin{array}{l}\text { Mengurangi } \\
\text { kesalahan pada } \\
\text { proses request } \\
\text { material }\end{array}$ & $\begin{array}{l}\text { Mekanik melakukan } \\
\text { double check ketika } \\
\text { menulis material } \\
\text { kedokumen }\end{array}$ & & $\begin{array}{c}\text { Line } \\
\text { Produksi }\end{array}$ & Produksi \\
\hline \multirow[b]{2}{*}{9} & \multirow[b]{2}{*}{$\begin{array}{l}\text { Sertifikat } \\
\text { material } \\
\text { kurang karena } \\
\text { tim material } \\
\text { kurang teliti }\end{array}$} & \multirow{2}{*}{$\begin{array}{l}\text { Personel material } \\
\text { melakukan double } \\
\text { check ketika } \\
\text { melengkapi } \\
\text { sertifikat material } \\
\text { ke dokumen }\end{array}$} & \multirow[b]{2}{*}{$\begin{array}{l}\text { Meningkatkan } \\
\text { kecepatan } \\
\text { closing dokumen }\end{array}$} & $\begin{array}{l}\text { Melakukan double } \\
\text { check ketika } \\
\text { melengkapi } \\
\text { dokumen }\end{array}$ & & $\begin{array}{c}\text { Line } \\
\text { Produksi }\end{array}$ & Produksi \\
\hline & & & & $\begin{array}{l}\text { Personel material } \\
\text { harus selalu } \\
\text { menduplikat } \\
\text { sertifikat yang baru } \\
\text { datang atau baru } \\
\text { dibuat untuk back up } \\
\text { data }\end{array}$ & & $\begin{array}{c}\text { Line } \\
\text { Produksi }\end{array}$ & Produksi \\
\hline 10 & $\begin{array}{c}\text { Mesin printer } \\
\text { atau scan rusak } \\
\text { karena } \\
\text { kurangnya } \\
\text { perawatan }\end{array}$ & $\begin{array}{l}\text { Meminta unit } \\
\text { facillity untuk } \\
\text { melakukan servis } \\
\text { dan pengecekan } \\
\text { mesin secara berkala }\end{array}$ & $\begin{array}{l}\text { Menghindari } \\
\text { kerusakan mesin } \\
\text { printer atau scan }\end{array}$ & $\begin{array}{l}\text { Membuat jadwal } \\
\text { service mesin printer } \\
\text { dan scan yang } \\
\text { efektif }\end{array}$ & & $\begin{array}{c}\text { Line } \\
\text { Produksi }\end{array}$ & Facillity \\
\hline 11 & $\begin{array}{c}\text { Internet lambat } \\
\text { karena } u \text { ser } \\
\text { internet terlalu } \\
\text { banyak }\end{array}$ & $\begin{array}{l}\text { Menambah } \\
\text { bandwitch internet }\end{array}$ & $\begin{array}{l}\text { Mempercepat } \\
\text { proses pekerjaan } \\
\text { yang } \\
\text { berhubungan } \\
\text { dengan sistem }\end{array}$ & $\begin{array}{l}\text { Menambah } \\
\text { bandwitch internet } \\
\text { pada jaringan yang } \\
\text { digunakan. } \\
\text { Melakukan } \\
\text { maintenance } \\
\text { jaringan secara } \\
\text { berkala. } \\
\end{array}$ & & $\begin{array}{c}\text { Line } \\
\text { Produksi }\end{array}$ & IT \\
\hline
\end{tabular}


Tabel 4. Problem Identification and Corrective Action (PICA)

\begin{tabular}{|c|c|c|c|c|c|c|c|}
\hline No & Masalah & Perbaikan & Mengapa & Bagaimana & Kapan & Dimana & PIC \\
\hline \multirow[t]{2}{*}{12} & \multirow{2}{*}{$\begin{array}{l}\text { Jarak antar unit } \\
\text { berjauhan dan } \\
\text { kurangnya } \\
\text { fasilitas } \\
\text { transportasi }\end{array}$} & \multirow[t]{2}{*}{$\begin{array}{l}\text { Menambah fasilitas } \\
\text { transportasi }\end{array}$} & \multirow{2}{*}{$\begin{array}{l}\text { Memangkas } \\
\text { waktu pekerjaan } \\
\text { apabila pekerjaan } \\
\text { berkaitan dengan } \\
\text { unit lain }\end{array}$} & $\begin{array}{l}\text { Fasilitas transportasi } \\
\text { yang sudah ada } \\
\text { dilakukan } \\
\text { maintenance secara } \\
\text { berkala untuk } \\
\text { menghindari } \\
\text { kerusakan } \\
\end{array}$ & & $\begin{array}{c}\text { Line } \\
\text { Produksi }\end{array}$ & Facillity \\
\hline & & & & $\begin{array}{l}\text { Menambah fasilitas } \\
\text { transportasi } \\
\text { khususnya sepeda } \\
\text { dan mobil shuttle }\end{array}$ & & $\begin{array}{c}\text { Line } \\
\text { Produksi }\end{array}$ & Facillity \\
\hline
\end{tabular}

\section{KESIMPULAN DAN SARAN}

\section{Kesimpulan}

Berikut merupakan kesimpulan yang didapatkan dari penelitian yang telah dilakukan yaitu:

1. Keterlambatan (delay) yang terjadi saat delivery dokumen maintenance c-check pesawat adalah sebanyak 38 keterlambatan dari total 72 delivery dokumen, dengan breakdown delay terbanyak terjadi pada bulan November 2019 yakni sebanyak 10 keterlambatan delivery dokumen dan 5 ontime delivery dokumen dari total 15 pengiriman dokumen. Berdasarkan diagram fishbone dapat diketahui faktor-faktor yang menyebabkan delay delivery dokumen maintenance $C$-Check yaitu:

a. Man, yang meliputi :

1) Mekanik tidak stamp.

2) Menunggu dokumen di review QC.

3) Menunggu approval dari customer.

b. Method, yang meliputi :

1) Dokumen tidak lengkap.

2) Terlambat mengirim dokumen ke TJP-4.

3) Report inspeksi spesial proses tidak ada.

c. Material, yang meliputi :

1) Tidak menuliskan batch material

2) Sertifikat material tidak ada.

3) Sertifikat material kurang.

d. Machine, yang meliputi :

1) Internet lambat.

2) Mesin printer atau scan rusak.

e. Environment, yang meliputi :

Jarak antar unit berjauhan.

f. Berdasarkan hasil pengolahan FMEA, 3 faktor penyebab delay delivery dokumen maintenance $c$-check yang paling dominan yaitu:

1) Stamp pada dokumen tidak lengkap, dengan nilai RPN 16.

2) Menunggu approval costumer, dengan nilai RPN 16.

3) Sertifikat material tidak ada, dengan nilai RPN 12.

2. Corrective action yang diterapkan untuk meminimasi pemborosan (waste) yang paling dominan, yang ada dalam proses delivery dokumen maintenance c-check pesawat yaitu:

a. Untuk menangani masalah stamp pada dokumen tidak lengkap dapat dilakukan dengan beberapa tindakan berikut:

1) Manager melakukan briefing kepada sub koordinatnya mengenai pentingnya melakukan stamp pada dokumen setiap selesai pekerjaan (minimal per 3 hari). 
2) Memberikan sanksi administratif kepada mekanik yang tidak melakukan stamp.

b. Untuk menangani masalah menunggu approval costumer dapat dilakukan dengan beberapa tindakan berikut:

1) Segera mem-follow up pernyataan costumer apabila sudah terjadi kesepakatan.

2) Agreement hendaknya disertai email resmi atau statement letter.

c. Untuk menangani masalah sertifikat material tidak ada dapat dilakukan dengan beberapa tindakan berikut:

1) Mekanik melakukan double check ketika menulis material ke dokumen.

2) Memastikan material yang ditulis ke jobcard atau MDR sesuai dengan reference.

\section{Saran}

Berdasarkan peneitian yang dilakukan, berikut adalah saran untuk GM Hangar 4, project owner, personel quality control, mekanik, IT, facillity dan PPC di PT. GMF Aeroasia Tbk yaitu:

1. Melakukan pengawasan bersama dan meningkatkan kualitas hasil kerja sesuai prosedur yang berlaku.

2. Mengupayakan perbaikan proses terkait dengan komunikasi antar bagian, prosedur teknis dalam proses, seperti, standar pengisian dokumen, proses record dan aktivitas pendukung proses lainya.

3. Fokus untuk menjaga kualitas dan kepuasan customer dalam melakukan perawatan pesawat di PT. GMF-Aeroasia sesuai dengan agreement yang telah disepakati.

4. Melakukan evaluasi dalam setiap pengiriman yang mengalami keterlambatan dan dilakukan tindakan preventif agar tidak terulang.

5. Melakukan assessment dan penambahan personel QC dan PPC pada setiap capability pesawat yang dikerjakan oleh PT. GMF Aeroasia Tbk.

6. Melakukan perawatan atau maintenance berkala untuk alat-alat dan system yang berpotensi mempercepat pekerjaan delivery dokumen.

7. Melakukan penambahan fasilitas transportasi sehingga pekerjaan yang berhubungan dengan unit lain bisa lebih cepat.

8. Melakukan double check atau double back up data pada setiap pekerjaan sehingga menghindari kesalahan diawal dan penumpukan pekerjaan di akhir.

\section{DAFTAR PUSTAKA}

Adi, I., Jabbar, M.R., \& Elisabeth, G. (2013). Aplikasi Metode Taguchi Analysis Dan Failure Mode And Effect Analysis (FMEA) Untuk Perbaikan Kualitas Produk Di PT. XYZ, Jurnal Teknik Industri FT USU, Vol 2, No. 2, Juni 2013 pp. 13-18

Akhmad, J., Wahyu, E.S., \& Ilyas, M. (2014). Pengurangan Waste Menggunakan Pendekatan Lean Manufacturing, Jurnal Ilmiah Teknik Industri, Vol. 13, No. 1, ISSN 1412-6869

Gaspersz, V. (2007). Lean Sigma For Manufacturing And Service Industries. Jakarta: PT. Gramedia Pustaka Utama.

Hanik, R.U., Budi, S., \& Nani, K. (2015). Perencanaan Manhours C-Check Maintenance Pada Unit Base Maintenance PT. GMF Aeroasia, Jurnal Teknik Industri FT USU Vol 3, No. 3, pp. 8-14

Hilma, R.Z dkk. (2018). Failure Modes And Effects Analysis (FMEA) For Evaluation of A Sugarcane Machine Failure, MATEC Web of Conferences 204, 01012

Kumar, P., \& Arvind, K. (2016). Methods For Risk Management Of Mining Excavator Through FMEA And FMECA, The International Journal Of Engineering And Science (IJES) Volume 5, Issue 6, Pages 57-63

Liker, J. K. (2006). The Toyota Way: 14 Prinsip Manajemen, Jakarta : Erlangga

McDermott, R.E., Raymond, J.M., \& Michael, R.B. (2009). The Basics of FMEA. New York : Taylor \& Francis Group 
Shift Indonesia - Diagram SIPOC - Jumat 20 Desember 2019 -

http://shiftindonesia.com/sipoc-diagramlean-six-sigma-tool/

Singha, M., \& Debasis, S. (2017). Project Risk Analysis For Elevated Metro Rail Projects Using Fuzzy Failure Mode And Effect Analysis (FMEA), International Journal of Engineering Technology Science and Research, Volume 4, Issue 11

Tsai, S.B dkk. (2017). Combining FMEA With DEMATEL Models To Solve Production Process Problems, CIRP Conference on Manufacturing Systems, Volume 41, pp. 614-619

Wang, Z.L dkk. (2017). Failure Mode and Effect Analysis using Soft Set Theory and COPRAS Method, International Journal of Computational Intelligence Systems, Vol. 10. 1002-1015 